Section Editor

Mitchell S.V. Elkind,

MD, MS

Chenjie Xia, MD

François Dubeau, MD

Address correspondence and reprint requests to Dr. Chenjie Xia, Neurology Department, Montreal Neurological Institute and Hospital, 3801 University St., Montreal, Quebec H3A 2B4, Canada

chenjie.xia@mail.mcgill.ca

Supplemental data at www.neurology.org

\title{
Teaching Video NeuroImages: Dystonic posturing in anti-NMDA receptor encephalitis
}

自

A 27-year-old woman presented with odd behavior, seizures, and left arm paroxysmal dyskinesia, more specifically dystonic posturing (video 1 on the $\mathrm{Neu}$ rology ${ }^{\circledR}$ Web site at www.neurology.org), with no electrographic correlate on EEG. The diagnosis of anti-NMDA receptor encephalitis was confirmed by detecting serum and CSF anti-NMDA receptor antibodies. No ovarian teratoma was found, despite its association with this syndrome. She improved minimally with steroids, IV immunoglobulin, and plasmapheresis, but eventually responded to rituximab (video 2). We have not yet fully grasped the pathophysiology of paroxysmal dyskinesias in antiNMDA receptor encephalitis. ${ }^{1}$ Extensive EEG monitoring of this patient almost certainly rules out an ictal origin. Involvement of dopaminergic pathways has recently been hypothesized. ${ }^{2}$

\section{REFERENCES}

1. Iizuka T, Sakai F, Ide T, et al. Anti-NMDA receptor encephalitis in Japan: long-term outcome without tumour removal. Neurology 2008;70:504-511.

2. Dalmau J, Gleichman AJ, Hughes EG, et al. AntiNMDA-receptor encephalitis: case series and analysis of the effects of antibodies. Lancet Neurol 2008;7:10911098. 


\title{
Neurology
}

\author{
Teaching Video NeuroImages: Dystonic posturing in anti-NMDA receptor encephalitis \\ Chenjie Xia and François Dubeau \\ Neurology 2011;76; e80 \\ DOI 10.1212/WNL.0b013e3182166dde
}

\section{This information is current as of April 18, 2011}

\author{
Updated Information \& \\ Services \\ Supplementary Material \\ References \\ Subspecialty Collections \\ Permissions \& Licensing \\ Reprints
}

including high resolution figures, can be found at: http://n.neurology.org/content/76/16/e80.full

Supplementary material can be found at: http://n.neurology.org/content/suppl/2011/04/16/76.16.e80.DC1

This article cites 2 articles, 1 of which you can access for free at: http://n.neurology.org/content/76/16/e80.full\#ref-list-1

This article, along with others on similar topics, appears in the following collection(s):

Paraneoplastic syndrome

http://n.neurology.org/cgi/collection/paraneoplastic_syndrome

Information about reproducing this article in parts (figures,tables) or in its entirety can be found online at:

http://www.neurology.org/about/about_the_journal\#permissions

Information about ordering reprints can be found online:

http://n.neurology.org/subscribers/advertise

Neurology ${ }^{\circledR}$ is the official journal of the American Academy of Neurology. Published continuously since 1951, it is now a weekly with 48 issues per year. Copyright Copyright @ 2011 by AAN Enterprises, Inc.. All rights reserved. Print ISSN: 0028-3878. Online ISSN: 1526-632X.

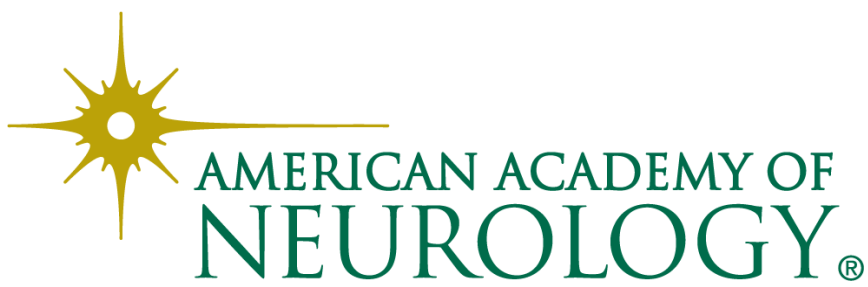

